\title{
BIOACTIVITY RESEARCHING ON NEW SPECIES OF ECHINOPS L. (ASTERACEAE): ANTIMICROBIAL AND ANTIOXIDANT ACTIVITY OF ECHINOPS ANTALYENSIS
}

\author{
Handan ŞAPCI ${ }^{1,}{ }^{*}$, Cem VURAL ${ }^{2}$ \\ ${ }^{1}$ Vocational School of Aladağ, Department of Forestry, Çukurova University, Adana, Turkey \\ ${ }^{2}$ Department of Biology, Faculty of Science, Erciyes University, Kayseri, Turkey
}

\begin{abstract}
The aim of this study was to investigate the antimicrobial and antioxidant activities of different extracts from Echinops antayensis C.Vural. Antimicrobial activity was estimated against several common human pathogenic bacterial strains using the agar disc diffusion and minimum inhibitory concentration assays. Antioxidant activity was evaluated using the DPPH radical-scavenging assay and total phenolic content methods. On the light of these experiments, E. antalyensis would seem to be an important natural antioxidant. This study is first report on the biological activity of $E$. antalyensis as regarded new species from Turkey.
\end{abstract}

Keywords: Anti-bacterial, Antifungal, Composite, Phenolic content, Plant extracts

\section{INTRODUCTION}

Plants play a pivotal role in the health care of ancient and modern cultures. Plant based drugs or formulations are used to treat various human diseases because they contain the components of therapeutic value. In addition, plant based cures remain an important source of therapeutic agents because of the availability, relatively cheaper cost and non-toxic nature when compared to modern medicine [1-5].

In order to bring pathogenic organisms under control, the use of numerous aromatic herbal essences with antimicrobial activity has been employed. Disc diffusion and microdilution methods are commonly applied in antimicrobial activity tests.

Antioxidants are used for struggle against oxidative stress and damage which pro-oxidants may cause in foods, environment and organisms. Several antioxidant determining methods have been developed in order to define the usability of plants, the natural antioxidant resources, for this purpose. Total phenolic material determination and DPPH radical scavenging activity definition are amongst the commonly used methods. Phenolic materials compose the most important groups of natural antioxidants and these materials are the basic components of plants [6].

As a result of studies carried out with Echinops from the Asteraceae family up to the present, it has been proven that taxa of the Echinops species are effective against migraine, intestinal worms, hemorrhoid, piles, diarrhea, heartache as well as various infections and it has been concluded that they have a wide usage area as an alternative treatment method [7]. The purpose of the present study was to investigate the antimicrobial and antioxidant activity of E. antalyensis.

\section{MATERIAL AND METHODS}

\subsection{Plant material and Preparation of Extracts}

Echinops antalyensis were collected during the project supported by TUBITAK (106T526). These specimens were deposited in the Herbarium of Erciyes University, Turkey. Fresh plant material was 
washed with tap water. Then it was air dried and chopped into small parts. The powdered material was extracted with $\mathrm{n}$-hexane, methanol and chloroform (CHL). Ten grams $(10.0 \mathrm{~g})$ of plant sample was extracted seperately in $200 \mathrm{ml}$ of $\mathrm{n}$-hexane, methanol and chloroform (CHL)by using a soxhlet extractor. After one day of dissolving process, materials were filtered (Whatman no. 1 filter paper). The extract was concentrated by Rotary-evaporator (Heidolph, laborota 4000) at reduced pressure below $50^{\circ} \mathrm{C}$ and the extract was then stored in refrigeratör at $4^{\circ} \mathrm{C}$ for further studies.

\subsection{Microorganisms}

The extracts of E. antalyensis were assessed against 14 bacteria including Gram-positive bacteria such as; Staphylococcus aureus ATCC 25923, Enterococcus faecalis ATCC 29212, Staphylococcus epidermidis ATCC 12228, Micrococcus luteus ATCC 10240, Listeria monocytogenes ATCC 19115, Bacillus cereus ATCC 11778, Bacillus subtilis ATCC 6633, Corynebacterium renale ATCC 19412 and Gram-negative bacteria as Klebsiella pneumoniae ATCC 13883, Pseudomonas fluorescens ATCC 49838, Enterobacter aerogenes ATCC 13048, Escherichia coli ATCC 25922, Proteus mirabilis ATCC 25933, Pseudomonas aeruginosa ATCC 27853 and a fungi Candida albicans ATCC 90028.

\subsection{Antimicrobial Activity Test}

The agar disc diffusion and minimum inhibitory concentration methods (MIC) were employed for the determination of antimicrobial activity of $E$. antalyensis.

\subsubsection{Agar Disc Diffusion Assay}

Disc diffusion tests were carried out by method of National Committee for Clinical Laboratory Standards [8]. The dried plant extracts were dissolved in dimethyl sulfoxide (DMSO). Pure bacterial strains were suspended in Tryptic Soy Broth (TSB, for bacteria) and Yeast Pepton Dextrose Broth (YPDB, for fungi). The optical density was adjusted to 0.1 at $570 \mathrm{~nm}$ (Shimadzu UV 1800 spectrophotometer). A suspension of the tested microorganism was spread on the solid media plates. Whatman paper disc $(1 \mathrm{~mm})$ was impregnated with $30 \mu \mathrm{l}$ of the extracts and inoculated discs were placed on the plate. After staying at $4{ }^{\circ} \mathrm{C}$ for $2 \mathrm{~h}$, then micoorganisms were incubated at $37^{\circ} \mathrm{C}$ for $24 \mathrm{~h}$. Pure DMSO was used as negative control and standard antibiotics (ampicillin, tetracycline and nystatin) were used as positive control. The diameters of the inhibition zones were measured in millimeters. All the tests were run in duplicated.

\subsubsection{Determination of Minimum Inhibitory Concentration (MIC)}

A minimum inhibition concentration (MIC) tests were carried out by National Committee for Clinical Laboratory Standards method and used in sterile 96-well micro plates [9]. Echinops antalyensis extracts were prepared as $1000 \mu \mathrm{g} / \mathrm{ml}$ for each solvent, methanol, chloroform, and hexane then transferred to each micro plate well in order to obtain a twofold serial dilution from 1:2 to 1:64. All tests were carried out in Mueller Hinton Broth (MHB), but except for the yeast (YPDB). Microplates were incubated at $37^{\circ} \mathrm{C}$ for $24 \mathrm{~h}$ for bacteria and $48 \mathrm{~h}$ for yeast. The bacterial growth was indicated by a white "pellet" on the well bottom.

\subsection{Antioxidant Activity}

E. antalyensis extracts were evaluated by using DPPH radical-scavenging and total phenolic content assay.

\subsubsection{1,1-Diphenyl-2-picrylhydrazyl (DPPH) Radical-Scavenging Assay}

The DPPH radical-scavenging activity of the extracts was assessed using the method [10]. Final extract concentration was adjusted at $200 \mu \mathrm{g} / \mathrm{ml}$. DMSO was added at $\% 0.2$ ratio (v/v) and the volume was filled 
in to $3 \mathrm{ml}$ with $100 \%$ ethanol. After the incubation at room temperature for a $30 \mathrm{~min}$, absorbance was read against a blank at $517 \mathrm{~nm}$. Ethanol was measured as blank. Inhibition of DPPH radical was calculated using the equation: $\mathrm{I}(\%)=100 \times\left(\mathrm{A}_{0}-\mathrm{A}_{\mathrm{S}}\right) / \mathrm{A}_{0}$, where $\mathrm{A}_{0}$ is the absorbance of the control (containing all reagents except test compound) and $A_{S}$ is the absorbance of the test sample). BHT was used as positive control. The $\mathrm{IC}_{50}$ value (\% 50 inhibitions) was determined. The assay was performed in triplicate and the mean value was reported.

\subsubsection{Total Phenolic Content Assay}

Total phenolic content was estimated by Folin Ciocalteu reagent [11]. A $10 \mathrm{ml}$ reaction mixture containing $0.06 \mathrm{mg} / \mathrm{ml}$ extracts of E. antalyensis, $0.5 \mathrm{ml}$ Folin Ciocalteu reagent and $0.05 \mathrm{ml} \mathrm{10 \%}$ $\mathrm{Na}_{2} \mathrm{CO}_{3}$ was prepared. The mixture was allowed to stand for $2 \mathrm{~h}$ at room temperature. Thereafter, the absorbance of the mixture was measured at $760 \mathrm{~nm}$. Folin Ciocalteu reagent containing $10 \% \mathrm{Na}_{2} \mathrm{CO}_{3}$ was measured as blank. Gallic acid was used as the standard. Total phenolic content of $E$. antalyensis was calculated in terms of Gallic acid equivalents per gram of the tested extracts.

\section{RESULTS AND DISCUSSION}

The percentage productivity for different extracts was $14.97 \%, 5.99 \%$ and $3.47 \%$ for methanol, chloroform and hexane, respectively. The antimicrobial activity of $E$. antalyensis extracts was estimated in vitro by agar disc diffusion method. Results of disc diffusion and MIC assay were given in Table 12. The disc diffusion assay results revealed that extracts of $E$. antalyensis showed inhibitory activity against $C$. renale, B. cereus and L. monocytogenes. The hexane extract has more inhibitory activity than other extracts. MIC results displayed different results from disc diffusion methods. $\mathrm{MeOH}$, hexane and chloroform extracts of $E$. antalyensis revealed inhibitory affect against all microorganisms at different concentrations. The methanol extracts of $E$. antalyensis had the strongest inhibitive activity on $B$. cereus at concentration of $1.5 \mathrm{mg} / \mathrm{ml}$ and on $P$. aeruginosa at concentration of $3.13 \mathrm{mg} / \mathrm{ml}$, while extracts The chloroform extracts of $E$. antalyensis had the highest inhibitive activity on $S$. aureus at concentration of $1.10 \mathrm{mg} / \mathrm{ml}$. There are really different results between disc diffusion and minimum inhibitory concentration methods. In this study, the microdilution method was more sensitive than disc diffusion. In the mentioned Kim and Kim [12] the disc diffusion method has some limitations compared with broth microdilution. The present study showed that extracts of $E$. antalyensis show the remarkable inhibition against the tested organisms.

E. antalyensis and synthetic antioxidant BHT through the free radical scavenging of $\mathrm{DPPH}^{*}$ is shown in Table 3. The analysis results showed that methanol extract of E. antalyensis had the highest DPPH scavenging activity among the other extracts. Chloroform extract of E. antalyensis had the lowest activity. When compared to the positive control, BHT, E. antalyensis extracts had greater activity.

Total phenolic content was estimated by using Folin-Ciocalteu reagent. Phenolic content of the different fractions of $E$. antalyensis was solvent dependent and expressed as milligrams of Gallic acid equivalent (GAE). Total phenolic contents of hexane, chloroform and methanol extracts of E. antalyensis were $25.67 \pm 0.044,24.97 \pm 0.036$, and $34.3 \pm 0.008 \mathrm{mg}$ Gallic acid equivalent/g, respectively (Fig. 1). The highest concentration of phenols was estimated in Methanol. Chloroform and hexane extracts contains considerably smaller concentration of phenols. 
Şapcı and Vural / Anadolu Univ. J. of Sci. and Technology C-Life Sci. And Biotech. 7 (1)-2018

Table 1. Antimicrobial Activity Results: MIC Assay (mg/ml)

\begin{tabular}{lccccccc}
\hline & Extracts of E. antalyensis & \multicolumn{4}{c}{ Antibiotics } \\
\hline & Hexane & Methanol & Chloroform & T & A & M \\
\hline S. aureus & 25 & 3.13 & 1.10 & 0.075 & 0.075 & - \\
E. faecalis & 25 & 12.5 & 8.95 & 0.625 & 0.075 & - \\
P. fluorescens & 25 & 12.5 & 8.95 & 0.125 & - & - \\
S. epidermidis & 25 & 6.25 & 8.95 & 0.125 & 0.075 & - \\
M. luteus & 25 & 6.25 & 8.95 & 0.075 & 0.075 & - \\
L. monocytogenes & 25 & 6.25 & 8.95 & - & 0.5 & - \\
B. cereus & 25 & 1.56 & 8.95 & 0.075 & 0.075 & - \\
K. pneumoniae & 25 & 25 & 8.95 & 0.31 & 0.125 & - \\
E. aerogenes & 6.25 & 25 & 8.95 & 0.31 & - & - \\
E. coli & 12.5 & 25 & 8.95 & 0.15 & 0.075 & - \\
B. subtilis & 25 & 25 & 35.8 & 0.15 & - & - \\
P. mirabilis & 25 & 12.5 & 8.95 & 0.5 & 0.075 & - \\
P. aeruginosa & 12.5 & 3.13 & 8.95 & 0.075 & - & - \\
C. renale & 12.5 & 12.5 & 8.95 & 0.075 & 0.25 & - \\
C. albicans & 12.5 & 12.5 & 8.95 & - & 0.25 & 0.25 \\
\hline
\end{tabular}

-: No MIC value measured. (A:ampicillin, T:tetracycline, N:nystatin)

Table 2. Antimicrobial Activity Results: Disc diffusion assay zone diameter (mm)

\begin{tabular}{lllllll}
\hline & Extracts of E. antalyensis & \multicolumn{3}{c}{ Antibiotics } \\
\hline & Hexane & Methanol & Chloroform & A & T & N \\
\hline S. aureus & - & - & - & 25.6 & 20.9 & 52.4 \\
E. faecalis & - & - & - & 26.1 & 8.3 & 32.5 \\
P. fluorescens & - & - & - & - & 13.6 & - \\
S. epidermidis & - & - & - & 38.8 & - & 20.6 \\
M. luteus & - & - & - & 33.2 & 26.3 & 43.5 \\
L. monocytogenes & 8.17 & - & 4.55 & 40 & 28.2 & 33.8 \\
B. cereus & 12.56 & 3.45 & 3.37 & - & 23.3 & 10.6 \\
K. pneumoniae & - & 3.41 & - & 29 & 20.5 & 12.9 \\
E. aerogenes & - & - & - & 25.2 & 17 & - \\
E. coli & - & - & - & 26.4 & 12.5 & 23.1 \\
B. subtilis & - & - & - & 39.7 & 25.3 & - \\
P. mirabilis & - & - & - & 20.2 & - & 28.3 \\
P. aeruginosa & - & - & - & - & 8.9 & - \\
C. renale & 7.36 & 6.86 & 6.13 & 29.2 & 28.4 & 60.2 \\
C. albicans & - & - & - & & & \\
\hline
\end{tabular}

-: No inhibition zone. (A:ampicillin, T:tetracycline, N:nystatin)

Table 3. DPPH radical scavenging activity of E. antalyensis extracts

\begin{tabular}{ll}
\hline Sample & DPPH IC $50(\mu \mathrm{g} / \mathrm{ml})$ \\
\hline Methanol extract & $86.36 \pm 0.002$ \\
Chloroform extract & $68.18 \pm 0.005$ \\
Hexane extract & $72.72 \pm 0.001$ \\
BHT & $48.03 \pm 0.24$ \\
\hline
\end{tabular}

\section{CONCLUSION}

When the literature studies were examined, there are several studies. In the past studies reported that some taxa of Echinops include compounds such as flavonoids, alkaloids, saponins, phytosterols, polyphenols, carotenoids, sesquiterpenes, lactones, alcohols, lignans, acetylenic, thiophen and essential oils [13-15]. For instance, Dawit and Ahadu (1993) state that some taxa of the Echinops have been used for the treatment of migraine, heart diseases, intestinal infestation, hemorrhoids and some other diseases 
[16]. Şapcı and Vural (2017) evaluated E. phaeocephalus of antimicrobial and antioxidant activity and the state that $E$. phaeocephalus should be used as potential antioxidant. In this study, the antimicrobial activity of $E$. antalyensis was evaluated fort he first time. In vitro antimicrobial activities of ethanol, methanol and hexane extracts of $E$. antalyensis had different antibacterial effects against antibioticresistant. The results of this paper obviously reported that the antimicrobial and antifungal activity could be change with used extracts. Also, the microdilution method was more sensitive than disk diffusion.

Our research and previous papers concerning the biological activities of Echinops species supposed that genus Echinops has important potential in antioxidant systems.

\section{ACKNOWLEDGMENTS}

Plant material used this study was supported by TUBITAK (Project no: TBAG 106T526).

\section{REFERENCES}

[1] Haslam E. Natural polyphenols (vegetable tannins) as drugs: possible modes of action. J Nat Products 1996; 59: 205-215.

[2] Farr BM, Salgado CD, Karchmer TB, Sherertz RJ. Can antibiotic-resistant nosocomial infections be controlled? Lancet Infect Dis 2001; 1: 38-45.

[3] Nguefack J, Somda I, Mortensen CN, Zollo PHA. Evaluation of five essential oils from aromatic plants of Cameroon for controlling seed-borne bacteria of rice (Oryza sativa L.), Seed Sci Technol 2005; 33: 397-407.

[4] Ali-Shtayeh M, Jamous RM, Al-Shafie JH, Elgharabah WA, Kherfan FA, Qarariah KH, Khdair IS, Soos IM, Musleh AA, Isa BA, Herzallah HM, Khlaif RB, Aiash, SM, Swaiti GM, Abuzahra MA, Haj-Ali MM, Saifi NA, Azem HK Nasrallah HA. Traditional knowledge of wild edible plants used in Palestine (Northern West Bank): A comparative study. J Ethnobiol. Ethnomed 2008; 4: 13.

[5] Nissen N, Evans S. Exploring the practice and use of Western herbal medicine: Perspectives from the social science literature. J Herb Med 2012; 2: 6-15.

[6] Rice-Evans CA, Miller NJ, Paganga G. Antioxidant properties of phenolic compounds. Trends Plant Sci 1997; 2: 152-159.

[7] Hymete A, Iversen TH, Rohloff J, Erko B. Screening of Echinops ellenbeckii and Echinops longisetus for biological activities and chemical constituents. Phytomed 2005; 12: 675-679.

[8] NCCLS - National Committee for Clinical Laboratory Standards. In Performance Standards for Antimicrobial Disk Susceptibility Tests: Approved Standard, NCCLS document A7, Wayne PA, 1997.

[9] NCCLS - National Committee for Clinical Laboratory Standards. In Performance standards for antimicrobial susceptibility testing: 9th information supplement. Document M100-S9, Wayne, PA, 1999.

[10] Cuendet M, Hostettmann K, Potterat O, Dyatmiko W. Iridoid glucosides with free radical scavenging properties from Fagraea blumei. Helv Chim Acta 1997; 80: 1144-1152. 
Şapcı and Vural / Anadolu Univ. J. of Sci. and Technology C-Life Sci. And Biotech. 7 (1)-2018

[11] Gamez-Meza N, Noriega-Rodriguez JA, Medina-Juarez LA, Ortega-Garcia J, Cazarez-Casanova $\mathrm{R}$, Angulo-Guerrero O. Antioxidant activity in soybean oil of extracts from Thompson grape bagasse. J Am Oil Chem Soc 1999; 76, 1445-1447.

[12] Kim JS, Kim Y. The inhibitory effect of natural bioactives on the growth of pathogenic bacteria. Nutr Res Pract 2007; 1: 273-278.

[13] Tadesse M, Abegaz B. A review of the Genus Echinops (Composite, Craude) in Ethiopia with Notes on Phytogeography and Chemistry. Proceedings of the 12th Plenary Meeting of AETFAT, 1990; 4 - 10 September, Hamburg.

[14] Singh RP, Pandey VB. Further flavonoids of Echinops niveus. Fitoterapia1994; 65(4): 374.

[15] Hymete A, Iversen TH, Rohloff J, Erko B. Screening of Echinops ellenbeckii and Echinops longisetus for Biological Activities and Chemical Constituents. Phytomedicine 2005; 12: 675-679.

[16] Dawit A, Ahadu A. Medicinal Plantsand Enigmatic Health Practicesof Northern Ethiopia, Birhanena Selam, Addis Ababa, Ethopia 1993; 37-44.

[17] Şapcı H, Vural C. Echinops phaeocephalus (Asteraceae) Türünün Antimikrobiyal ve Antioksidan Aktivitesi 2017; KSU J Nat Sci, 2017; 20 (4), 355-360 